資 料

\title{
淺野カーリット藍印（硝安入カーリット）製造に際し 淺野ドライヤーによる室內空気の乾燥に關する報告
}

緒 言

過監素酸アンモニアを主とする爆藥カーリットの爆發ガス中 には多量の監酸ガスを含み，坑內の使用には不便慗からず。已 に二，三改良品を製造し居れるが，更に硝酸アンモニアを調合 し，其の多量なる發生ガスを利用し監酸ガスを稀釋し，坑內の 使用に便ならしめんとし研究を行ひ來たりしが，已に其の成案 を得たり。然るに夏季濕潤なる季篩に於て砛酸アンモニアを取 扳ふ作業室內の空氣は之を乾燥する必要あり，初め冷凍裝置に より 作業室內の空氣を乾燥せんと企てしが高價なるのみなら ナ゙，鐵材其の他の金屬材料の使用制限あり，電動 機も入手し難き狀態にあり，而も幸にして新製品 淺野ドライヤーあるを以て之を使用し其の目的を 達せんと欲し，其の試驗裝置を作り，甚だ迅速に 且又容易に作業室內の空氣を乾燥し得る事を知り たり。依て右實驗裝置並に成績につき報告せんと す。

\section{裝置}

直巠 $250 \mathrm{~mm}$, 高さ $300 \mathrm{~mm}$ のトタン板製筒の

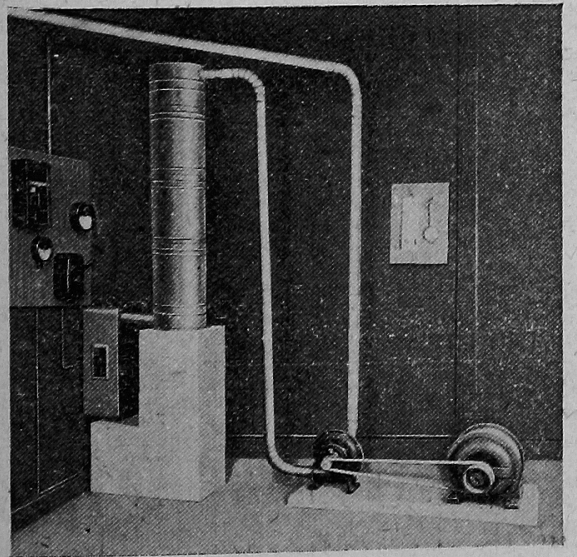

第1 圖乾燥裝置全景

*淺野カーリット株式會社技師長筷技術部長， 朝鮮淺野カーリット株式會社專務取締役
野 原 䊝 夫*

底部に荒目の金網を張り淺野ドライヤーの容器となし，ドライ ヤー約 $7.5 \mathrm{~kg}$ を充填す。ドライヤーの㒶の厚さは $290 \mathrm{~mm} に$ して容積は約 $18 l$ 即ち裝塤比重は約 0.4 なり。此の乾燥器 3 個を第2 圖 A の如く重ねて使用す。繼目より乾燥宾氣が逃れ去 らぬ爲に筒の上下端には鍔を付け簡單なるパっキングを施す。 作業室內の乾燥空氣を繰返し使用する目的を以て第 2 圖 $\mathrm{P}_{1}$ 管 により室內空氣を電動機 M にて運轉せる送風機 F にて引き更 に $\mathrm{P}_{2}$ 管にて乾懆塔 $\mathrm{BAB}$ に迩り込み空氣を充分に乾燥せしめ て溫度檢查器 $\mathrm{C}$ 及風速測定用管 $\mathrm{E}$ を經て作業䆓に䢪り返し, 室內の濕度を低下せしめたり。然るに送風機の運轉甼轉數は便
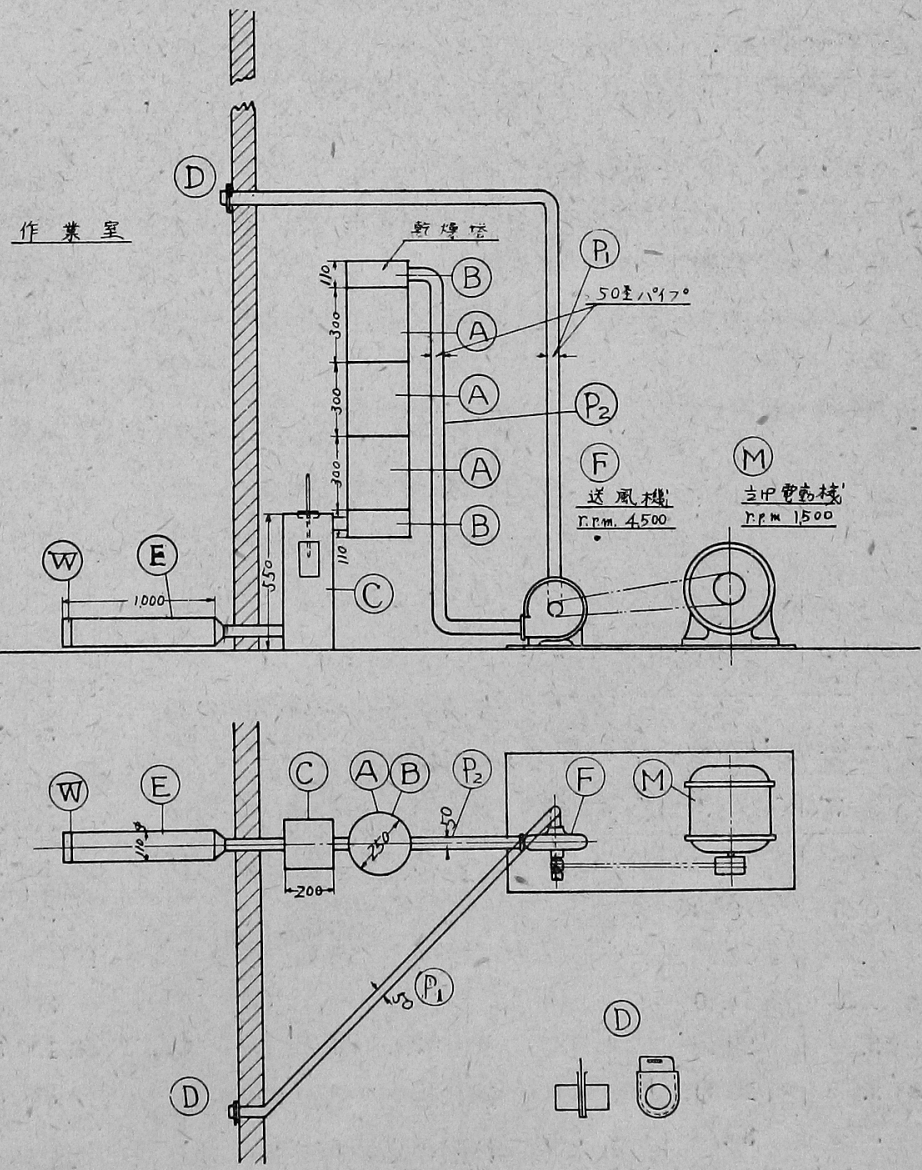

筙 2 圖 裝

谓 
宜上一定し度く，同時に室内空氣は一定の乾燥度に維持し，馀 分に乾燥せしめ奴爲に，ダンパーDを備へ作業室內にある乾濕 寒䁔計をみながら風量を調節せり。

檢査器Cはトタン板製箱にして前後側面に硝子空あり，上端

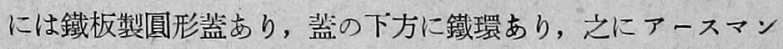
濕度計を吊し下げ 乾懆荅より出で去る空氣の乾懆度を測定せ b。風速測定用管 $\mathrm{E}$ は直徑 $110 \mathrm{~mm}$, 長さ $1000 \mathrm{~mm}$ のトタン 板製管にして，管端に風速計 $\mathrm{W}$ を取付け，風速並に風量を測 定せり。送風機 $F$ は口鱼 2 in，回轉數 4503 r.p.m. にして水

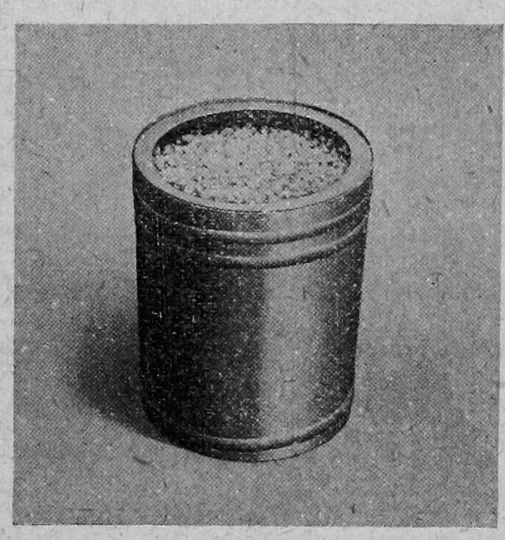

第 3 圖 ドライヤ一容器

柱 $100 \mathrm{~mm}$ の風黶 を生ず。管の接ぎ 目, 乾燥器の接ぎ 目等には紙テープ にて目張りをな し, 穴氣の漏出す る事を预防せり。 此の送風機の送風 量は無荷の場合 $69.77 /$ sec にして 乾燥塔を通過せし

むれば $37.4 l / \mathrm{sec}$ となれり。

ダンパーはトタン板製にして管の直徑 $50 \mathrm{~mm}$ ，之に 幅さ 65 $\mathrm{mn}$ のトタン板の端を直巠 $65 \mathrm{~mm}$ の牛圓となしたるものを㨂 入する樣に作り，夫を閉める程度は空の直巠の分數にて之を示 せり。

ダンパーを全開より次第にシボレば風量は次の如く調節し得 られたり。

第 1 表 ダンバーの開開と風量

\begin{tabular}{|c|c|c|}
\hline & $\begin{array}{l}\text { 風 } \\
(\mathrm{m} / \mathrm{sec})\end{array}$ & $\begin{array}{l}\text { 風 }(1 / \mathrm{sec}) \\
\text { 量 }\end{array}$ \\
\hline 全 & 3.92 & 37.4 \\
\hline $1 / 2$ & 3.05 & 29.0 \\
\hline $1 / 4$ & 2.07 & 19.7 \\
\hline
\end{tabular}

\section{第 2 表 風量々風原差}

\begin{tabular}{|c|c|c|}
\hline $\begin{array}{l}\text { 風 速 } \\
(\mathrm{m} / \mathrm{sec})\end{array}$ & $\begin{array}{l}\text { 風 } \\
(1 / \mathrm{sec})^{\text {量 }}\end{array}$ & $\begin{array}{l}\text { 風 暦 差 } \\
\text { 水杜 }(\mathrm{m} / \mathrm{m})\end{array}$ \\
\hline 0.52 & 4.96 & 2 \\
\hline 0.85 & 8.13 & 4 \\
\hline 1.14 & 10.86 & 6 \\
\hline 1.70 & 16.20 & 8 \\
\hline 2.14 & 20.40 & 13 \\
\hline 2.67 & 25.50 & 21 \\
\hline 3.74 & 35.70 & 32 \\
\hline 4.22 & 40.30 & 39 \\
\hline
\end{tabular}

$$
\text { ダンパーにより揆風機の }
$$
这風量を調節する時は, 乾 燥薣內に於て如何なる風壓 のドロップあるやを知らむ として,マノメターを乾燥 塔の前後に㨂み第 2 表の如 き成績を得たり。

作業室は長方形にて面積 2 坪あり，天井の高さ約 1.5 間にして其の內容積は 約 $17.5 \mathrm{~m}^{3}$ なり。而して高 さ 3 尺幅 1 間の空あり, 引 違ひ硝子戶を備へ, 出入口 は幅 3 尺高さ 6 尺にして腰 板張の硝子戸を備ふっ。
室の內壁はトタン板張となし空框等との間に出來るだけ隙間の 出來㨾に注意し，硝子戶の硝子はパテ止めとし，戶のの隙間に は板を打ち付け床はアスフデルト堯付けとなし通風を制限する と同時に，濕氣が徒らに信入する事を防げり。硝子戶の開閉及 多少の隐間による通氣により人の呼吸には何等差閭なし。作業 室內宾氣の濕度を全般に均一ならしめおき測定を行はんと欲し 扇風機にて靜かに空氣を㩭拌せり。濕度の測定は乾濕球寒援計 によれり。

\section{淺野ドライヤーの性質測定}

淺野ドライヤーに濕氣ある宾氣を通ずる時は，水分を吸收し て發熱す。かくしてドライヤーの溫度の變化を知り，同時に乾 燥塔より出で來る空氣の溫度及濕度を測定せり。

此の實驗に於ては絕えず故意に濕氣多き外氣を每秒約 $20 l$ 乾 燥塔に通風せしが，之は出來るだけ短時間に淺野ドライヤーの 吸濕能力を喪失せしめんが篤なりき。測定は約 9 時間に互りて 行へり。

大氣の溫度 $T$ 及濕度 $H$ は室內にて乾濕塞喛計にて測り, 乾 燥劑の溫度は其の中に插入したる寒暖計の愳みを取り，其の上 部とは新鮮なる宾氣が流大する乾燥荅の最上段を意味し，中部 とは其の次段を，下部とは此處より乾燥されたる室氣が流出す る最下段を意昧す。

此等溫度を夫々 $t_{1}, t_{2}$ 及 $t_{3}$ とす。乾燥空氣の溫度 $T_{1}$ 及濕度 h は檢査器 $\mathrm{C}$ 內に於てアースマン乾濕球濕度計にて測定せり。 此の乾懆空氣は乾燥劑の鵎に加熱され大氣溫よりも著しく上昇 し居れば，之を大氣溫に於る濕度に換算しh'として記載せり。 此等測定結果は次の第 3 表, 第 4 圖の如し。

$$
\begin{gathered}
\text { 第 } 3 \text { 表 淺野ドライャ一性質測定成績 } \\
\text { (昭和 } 15 \text { 年 } 4 \text { 月 } 20 \text { 日) }
\end{gathered}
$$

\begin{tabular}{|c|c|c|c|c|c|c|c|}
\hline 時刻 & \begin{tabular}{|c|} 
大氮中 \\
の濕度 \\
$(\%)$
\end{tabular} & 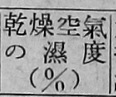 & $\begin{array}{l}\text { 大氣溫に } \\
\text { 換算せる } \\
\text { 愍 }(\%)\end{array}$ & 時刻 & \begin{tabular}{|c|} 
大㦱中 \\
क濕度 \\
$(\%)$
\end{tabular} & $\begin{array}{c}\text { 乾燥空穼 } \\
\text { क 瀑 度 } \\
(\%)\end{array}$ & $\begin{array}{l}\text { 大氣溫に } \\
\text { 換算せる } \\
\text { 愍度 }(\%)\end{array}$ \\
\hline 時 分 & $H$ & $h$ & $h^{\prime}$ & 時 分 & $H$ & $h$ & $h^{\prime}$ \\
\hline .15 & 76.5 & 0 & 0 & 15. 15 & 56.2 & 4.9 & 16.4 \\
\hline 35 & 68.0 & 15.0 & 7.1 & 35 & 54.2 & 4.5 & 14.5 \\
\hline 11. 15 & 58.6 & 8.9 & 26.0 & 16. 15 & 50.9 & 8.9 & 24.8 \\
\hline 35 & 57.9 & 7.3 & 23.2 & 35 & .50 .5 & 10.0 & 27.8 \\
\hline 12. 15 & 54.3 & 8.2 & 23.9 & 17. 15 & 49.9 & 9.6 & 23.4 \\
\hline 35 & 51.0 & 7.2 & 21.3 & 35 & 51.0 & 12.2 & 30.0 \\
\hline 13. 15 & 51.6 & 2.9 & 9.5 & 55 & 53.6 & 14.7 & 34.5 \\
\hline 5 & 52.0 & 2.7 & 9.0 & 18. 15 & 57.1 & 19.8 & 46.7 \\
\hline 15 & 53.1 & 5.6 & 17.8 & 35 & 59.0 & 23,7 & 52.6 \\
\hline 35 & 54.9 & 4.0 & 13.1 & 45 & 59.0 & 24.6 & 55.6 \\
\hline
\end{tabular}

備考 濕度とは關係濕度。 乾燥劑の溫度 $t_{1}, t_{2}, t_{3}$ 及び大氣溫度 $T$ は之を略せり。 


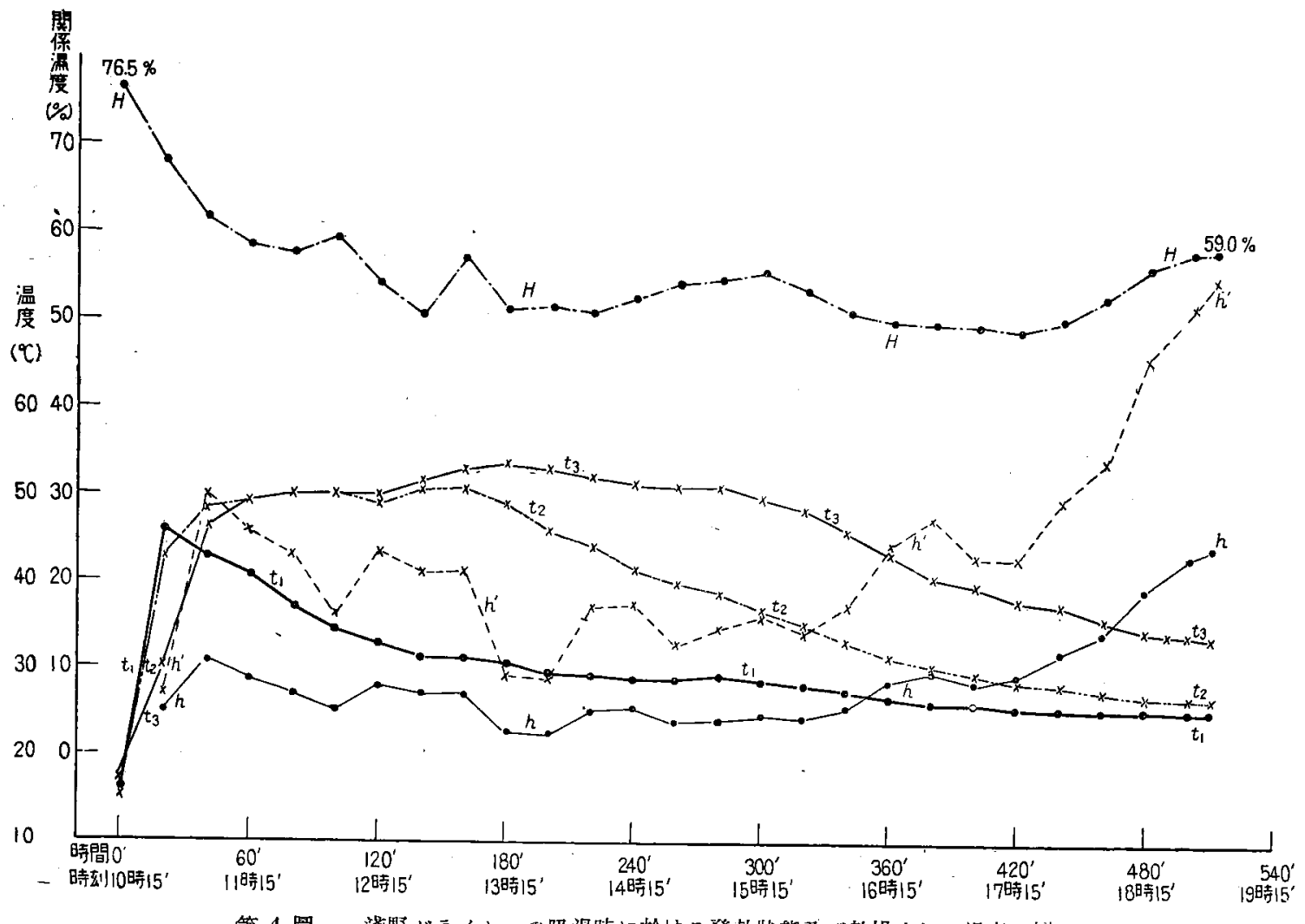

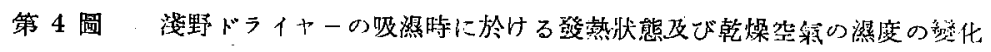

第4圖をみるに大氣中の濕度 $H$ は 10 洔頃 $76 \%, 12$ 時頃 $60 \% ; 12.5$ 時 $51 \%$ と次第に低下し 18 時預上り次第に上手せり。 乾燥空氣の潪度 $九$ は $8 \%$ より $2.14 \%$ となり, 17 時前 $10 \%$ に霄加し次第に上昇し，19特前には $25 \%$ となれり。而して大 氣溫に於る缹度 $h^{\prime}$ として計算せる結果も同樣なり。これ乾燥 劑の吸濕能力は初め增加する傾向あり, 叉6 時間位は變化なし と云ひ得べく，7時間を經過すれば吸濕能力次第に低下するも のなるべし。使用前後の乾煤劑の重量は次表の如く，吸濕量は 乾燤劑の $15 \%$ なり。 .. ・

第 4 表 乾燥前後の略沽量

\begin{tabular}{|c|c|c|c|c|}
\hline & 使用前 (gr) & 使用後 (gr) & 埖 量 ( $\mathrm{gr}$ ) & 百分率 $(\%)$ \\
\hline 上 & 7,500 & 8,820 & 1,320 & 17.6 \\
\hline 中 & 7,500 & 8,580 & 1,080 & 14.4 \\
\hline 下 & 7,500 & 8,410 & 910 & 12.2 \\
\hline & 22,500 & 25,810 & 3,310 & 平均 14.7 \\
\hline
\end{tabular}

乾燥劑の溫度上其は $t_{1}, t_{2}$ 及 $t_{3}$ 曲線共に初めは急に上昇し

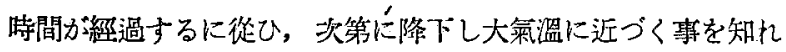
り。これ吸濕作用旺盛なる期間は濕度高きも，作用縓慢となる に從ひ溫度低下寸るものなるべし。依て乾懆劑の溫度は吸濕能 力の標示たり得ぺ。

$t_{2}$ は $t_{1}$ よりも後れ $t_{3}$ は $t_{2}$ よりも後れて，ほよ同形の腷線 を畫くことをみるべし。之により乾燥器を更新するには3個を
同時に取換へず，上部を取り去り，中及下部っ下に们收せるも のを置き，濕氮多き空氣は吸濕力衰へし上部に人り䏝潪力㕵盛 なる下部より放出さる」樣に作業するが最す合理的なるべし。

\section{作業室の乾燥}

上述岵燥塔を使用し上述作業室內の宾氣を乾燥せる試驗を述 べむ。

昭和 15 年 6 月 18 日雨天にして濕氣多きを以て此の日上記， 試驗を行ひ次の第 5 表及第 5 圖に示す成績を得たり。

第 5 裴 作業穻の乾燥試嬐成模

\begin{tabular}{|c|c|c|c|c|c|c|c|c|}
\hline \multirow{2}{*}{\multicolumn{3}{|c|}{ 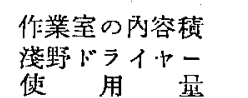 }} & \multirow{2}{*}{\multicolumn{2}{|c|}{$\begin{array}{r}18.3 \mathrm{~m}^{3} \\
26,860 \mathrm{gr}\end{array}$}} & & \multirow[b]{2}{*}{3} & \multicolumn{2}{|c|}{$38.4 l ;$ sec } \\
\hline & & & & & & & & $960 \mathrm{gr}$ \\
\hline \multirow{2}{*}{ 乾燥洔剂 } & \multicolumn{2}{|c|}{ 作 } & \multicolumn{2}{|c|}{ 室 } & \multicolumn{2}{|r|}{ 大 } & \multicolumn{2}{|c|}{ 饿 } \\
\hline & 溫 & 度 & 濕 & 度 & 温 & 度 & 涊 & 度 \\
\hline 時 分 & & $(\mathrm{C})$ & & $(\%)$ & & $(\bar{C})$ & & $(\%)$ \\
\hline 14. 15 & & 20.0 & & 89.0 & & 20.1 & & 91.3 \\
\hline 25 & & 20.5 & & 75.0 & & 20.3 & & 90.4 \\
\hline 35 & & 20.0 & & 61.0 & & 20.2 & & 90.3 \\
\hline 45 & & 20.1 & & 56.7 & & 20.4 & & 89.0 \\
\hline 55 & & 20.9 & & 53.4 & & 20.3 & & 90.4 \\
\hline 15. 05 & & 21.0 & & 49.0 & & 20.2 & & 91.4 \\
\hline 15 & & 21.1 & & 47.1 & & 20.4 & & 89.0 \\
\hline 25 & & 21.2 & & 47.2 & & 20.4 & & 89.0 \\
\hline 35 & & 21.5 & & 47.5 & & 20.5 & & 89.0 \\
\hline 45 & & 21.6 & & 46.9 & & 20.5 & & 89.0 \\
\hline 55 & & 21.8 & & 45.0 & & 20.6 & & 89.0 \\
\hline
\end{tabular}




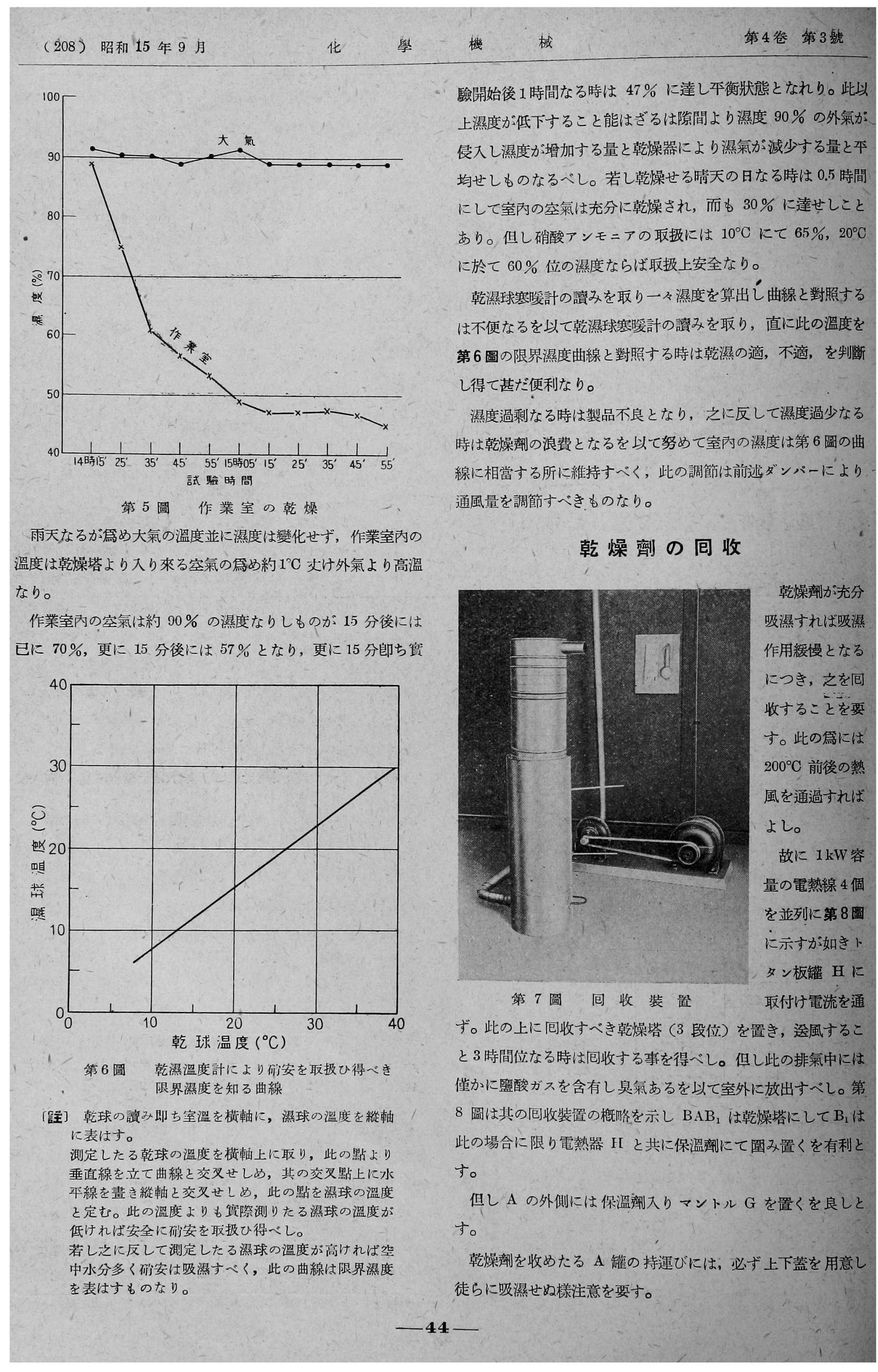



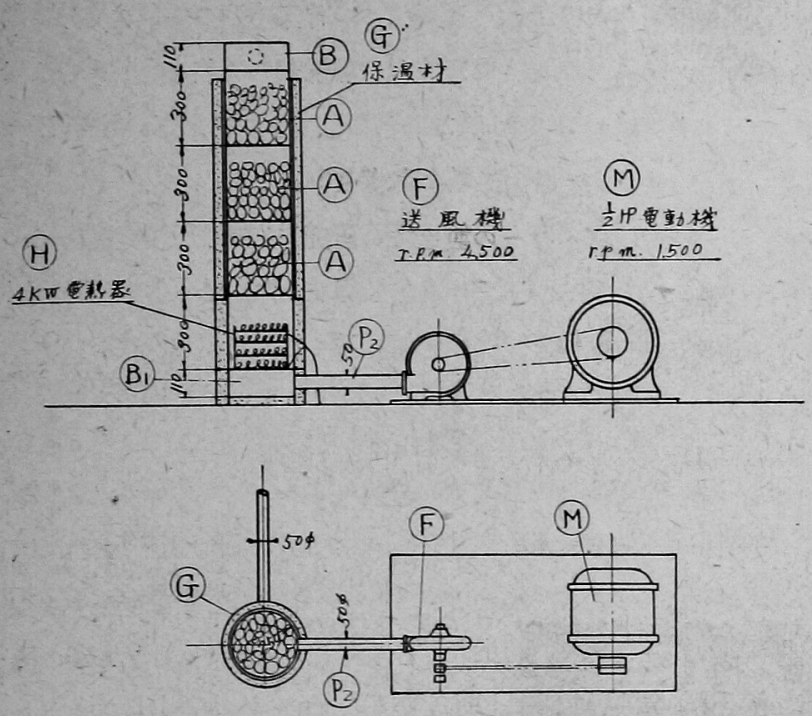

第 8 圖乾燥前包收裝置

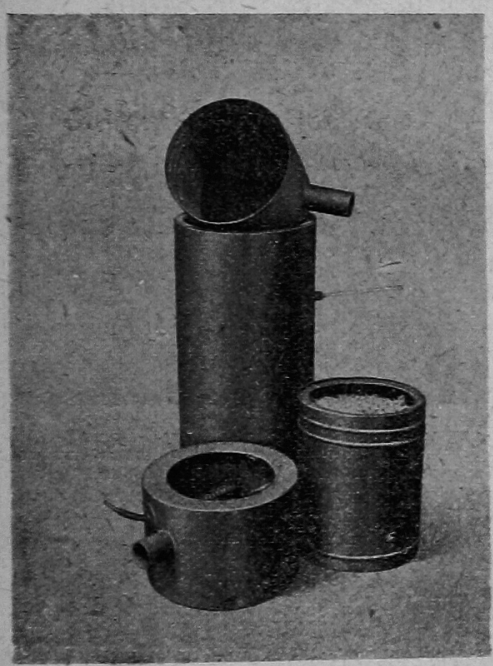

第 9 圆回收荘置分解

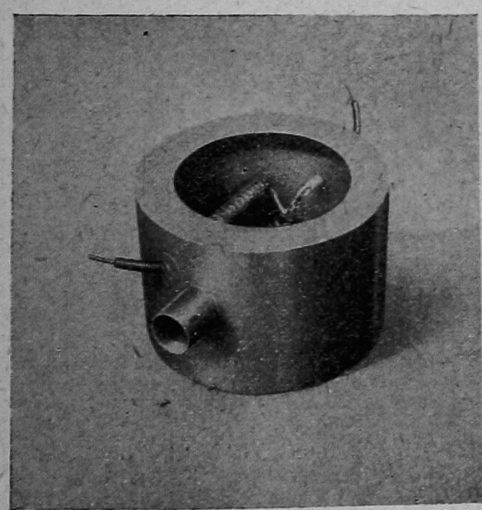

第 10 圖回收用電熱器

電熱器に電流を通 じ邆風機を運轉し風 量はダンパーを使用 乙通氣を調節乙約 $20 \mathrm{t} / \mathrm{sec}$ とし, $200^{\circ} \mathrm{C}$ 位の熱室氣を乾燥劑 に途入す。

此の時乾燥劑中の アケ所に挿入したる 寒暖計及出口に置き たる寒喛計の讀みを 取れり。其の結果は 第 11 圖の如し。 熱風の入口, 郎ち 最下段の乾燥枚は $200^{\circ} \mathrm{C}$ の熱風に堛ま れながら直ちに高溫 となること能はず, 漸次溫度が上年し 1.5 時間位にして始 て $190^{\circ} \mathrm{C}$ に達し, 更 に200 $\mathrm{C}$ に上昇した かと思ひしに再び $190^{\circ} \mathrm{C}$ に低下せり。 これ初め熱は吸濕せる水分が蒸發するに必要なる, 即ち蒸發潜 熱に振向けられ，蒸發が旺盛なる間は溫度上昇し難く, 蒸發が 多少緩慢となるに從ひ溫度は次第に上昇するものにして, 一旦 上梨せる溫度が低下せしは，電洭が低下し電流が減退せしによ

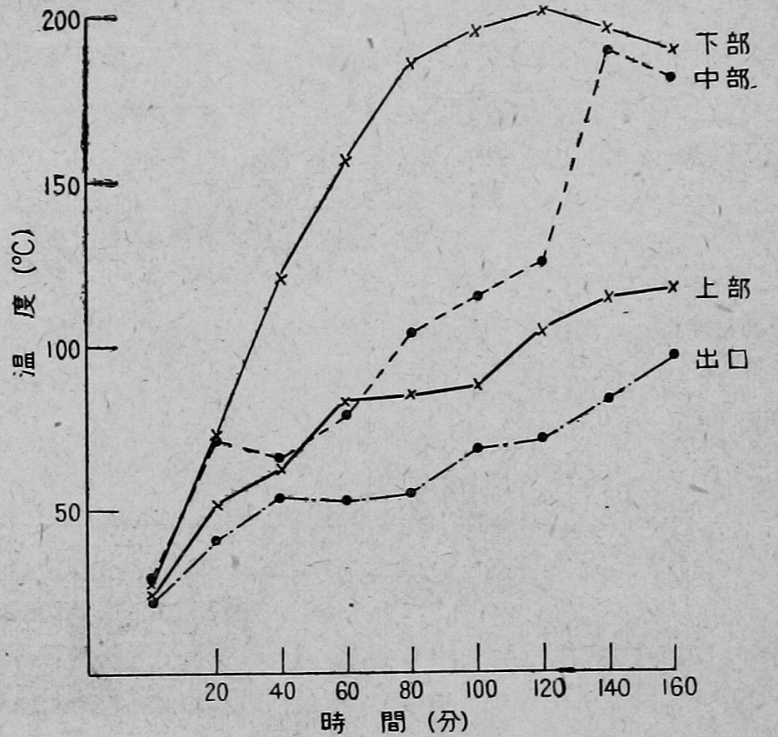

第 11 圖吸滋ドライャーの回收成績

るならん。次に中段の溫度は $70^{\circ} \mathrm{C}$ となるまでの經過は下部と 同樣なりしが, $106^{\circ} \mathrm{C}$ となるには下部より 50 分間位後れ， $190^{\circ} \mathrm{C}$ に上昇するにも下部より約 50 分間後れたり。これ下部

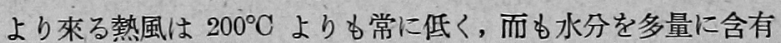
すれば，溫度が上昇する㼣には餘分に手間取るすのなるぺし。 熱風の出口郎ち最上段は中段よりも更に後れて包收さるるも のにして, 出口郎ち排氣の溫度は 1 時間餘り約 $50^{\circ} \mathrm{C}$ を維持し て後，始めて少し宛上昇し 2 時間後に $80^{\circ} \mathrm{C}$ となる。 淺野ドライヤーが吸濕せし堌量及包收せし後の減量は第 6 表 の如し。

第 6 表 淺野ドライトーの重量の變化

\begin{tabular}{|c|c|c|c|}
\hline & 下 部 & 部 & 上 部 \\
\hline 使用前の重量 (gr) & 7,500 & 7,500 & 7,500 \\
\hline 吸然後 " (") & 8,820 & 8,580 & 8,410 \\
\hline 量 ("I) & 1,320 & 1,080 & 910 \\
\hline 量 (\%) & 17.6 & 14.4 & 12.3 \\
\hline 回收前の重量 ( $g r$ ) & 8,820 & 8,580 & 8,410 \\
\hline 回收後 " (") & 7,360 & 7,720 & 8,200 \\
\hline 量(") & 1,460 & 860 & 210 \\
\hline 量 (\%) & 16.6 & 10.0 & 2.5 \\
\hline
\end{tabular}

包收狀態は下段は完全なり。これ使用前よりも包收後の方乾 燥劑の重量小となり居るをみれば明暸なるへし。之に反して中 段は $220 \mathrm{gr}$ 丈け餘分の水分が殘留し回收不充分なるが，上段は $700 \mathrm{gr}$ 餘分の水分が殘留すれば司收は一層不充分なり。概して 一段にのみついては $180^{\circ} \mathrm{C}$ 又は $200^{\circ} \mathrm{C}$ の溫度を約 1 時間維持 せしむれば其段の乾燥前の包收は完全に行はる。

回收されたる熱き罐は上下に蓋をなし，郎ち吸濕せぬ用意の 
下に冷却し使用するものにして，此の问收されたる段は乾燥荅 の最下部，郎ち乾燥空氣の出口に置くべし。而して常に乾燥荅 の最上部の段を取り去り四收を行ふべし。

\section{結}

\section{$\overline{\overline{\bar{一}}}$}

直俓 $250 \mathrm{~mm}$, 厚さ $290 \times 3=870 \mathrm{~mm}$, 重量 $7.5 \times 3=22.5 \mathrm{~kg}$ の乾燥䰜に 1 秒に付き約 $20 l$ の宾氣を暌人する時は，濕度 $5 \%$
位の乾懆空氣が得られ，乾燥すべき作業室內の空氣も充分に乾 燥さるること分明し，吸濕したる乾懆劑の司收も容易に行ひ得 ることも分明したるを以て，直に此の裝置を擴大し朝鮮淺野カ ーリット株式會社鳳山工場に設備せり。

此の淺野ドライヤーの製造並に研究に從事され居る城輝之 今川博, 不川浩三の三氏の助言を得て上記計畫をなし，井田正 二氏專ら此の實驗を行へら。茲に厚く感謝の意を表す。

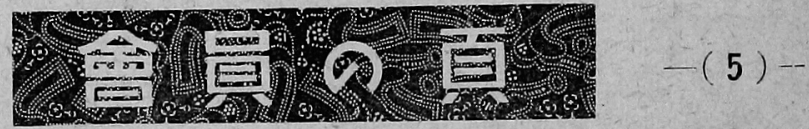

\section{若き技術者の幻影}

$\mathrm{K} \quad \mathrm{O}$ 生

私は某大學の應用化學科を今春卒業したばかりの靑二才 である。勤務先はこれ又時勢の要求によりて生れ出たばか りの某會社の研究所である。其處には溫度測定にポテン ショメーターはおろかミリボルトメーターさへ見當らな い。氣の利いたアンメーター，ボルトメーター等の無いこ とは云ふ迄もない。

私は工業技獄の研究には益々精密な測定と系統的解析的 實驗法が必要であると考へてるた。今此處に將來の自分の 方針に對し一考せざるを得ない立場に置かれた。

私は何の丞めに工業技術の最高學府を卒業したか, 多く の大學卒業生中には單に支配者的立場たらんとする希望に 燃えてるる者もあろ3。五國家的立場に立ちて技術气のも のを批判してるる者もあろら。彼等にとつては恐らく工業 技術は第二或は第三的の存在にしか過ざないだろろ。然し 私自身は未熟乍ら生涯を技術の鴊めに生きたいと思つてる た。學校に學び知つた科學と此後讀書によつて得られてゆ く知識を活用し,實際に當つて少しでも精密な測定と,解析 的實驗に志し high efficieney の見事なる裝置を design

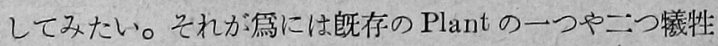
にしてもよいのではないかと考へてるる。然し人は言ふ,
それ迄やらなくても大方の計算で立派に間に合ふ2 Plantが 出來ると。然り經濟的立場から大きな目で見たら精密なる 實驗よりひ一日も早く Plant を作つて操業した方が利益 であるに違ひない。然らば工業技獄者とは何でや。“そは 單なる Plant の keeper なり”と解されねばならぬ現狀 だ。

確かに工業技術は工業の必要より生れた。然し人間が猿 より進化して猿以上の價值を有するに至つた如く，工業技 術は單なる經学的工業の立場を離れて，科學と工業とを結 びつけるそれのみにて價值ある學として成立しないであら らか。藝術は娛樂より進化したものであらう。然し立派に 壆術として古今に生命を有しむしろ健全なる娛樂を導い てるる。吉川氏の宮本武藏は劍を以て果しない人格の向上 に資したと云ふっ。私達技術者は，技術の鍊磨を通して人格 の糧となすことは出來ないのであらうか。

科學的，技術的立場より見事に desi n されれたつ゚ラン ト，極度に自動化され，しかも初めの計畫通りに動く全機 能，そは調和せる美を求める藝術の世界でなくして何ぞ や。か〉る技術の境地を開かん鹂には，極め難き科學の奧 義の理解と果しなき技術の錄磨とを必要とするのである。 鳴呼私は欲する。立派なる指導者と、寬大なる企業家を。

夢は果しなく美を求めてゆく。然し，現實をふっりかへつ てみれば，人間も亦單なる資源にしか數へられてるない時 勢である。 